\title{
Exploring Collaborative Learning with a Focus on Group Activities in EFL Classrooms
}

\section{Ebru Melek Koç}

Inonu University, English Language Teaching Department

\begin{abstract}
:
This study aims to investigate the views of English-language teachers and their students with respect to collaborative learning (CL) and more specifically, with respect to group activities. The study included 25 Turkish English-language teachers and their 486 EFL (English as a Foreign Language) students. The data were collected from separate questionnaires completed by the students and the teachers. Additionally, four teachers and 10 students were interviewed. The percentage of responses for each option of each question was calculated for each item on both questionnaires. The recorded interviews were analysed through content analysis. The results indicate that most of the students favor group activities in the classroom, whereas the teachers exhibit far less enthusiasm for group activities because of difficulties associated with classroom management and excessive noise levels generated during group activities. It is suggested that teachers receive training in $C L$ so that they can effectively implement the technique in the classroom and teach their students how to effectively use their interactional skills during $C L$ activities.
\end{abstract}

Keywords: cooperative and collaborative learning, group work, EFL classrooms, English as a foreign language

\section{İnönü University}

Journal of the Faculty of Education

Vol 19, No 3, 2018

pp. $582-597$

DOI: 10.17679/inuefd.385741

Suggested Citation

Koç, E.M. (2018). Exploring Collaborative Learning with a Focus on Group Activities in EFL Classrooms, Inonu University Journal of the Faculty of Education, 19(3), 582-597. DOI: 10.17679/inuefd.385741 


\section{Yabancı Dil olarak Ingilizcenin Öğretildiği Sınıflarda Grup Aktivite Odaklı Işbirlikçi Öğrenmenin Incelenmesi}

\section{Ebru Melek Koç}

Inönü Üniversitesi, Ingilizce Öğretmenliği Bölümü

\begin{abstract}
Özet:
Bu çalışma Ingilizce öğretmenlerinin ve onların öğrencilerinin işbirlikçi öğrenmeye, daha detaylı olarak grup aktivitelerine karşı görüşlerini araştırmayı amaçlamaktadır. Çalışmada 25 Türk Ingilizce öğretmeni ve onların 486 öğrencisini kapsamaktadır. Veriler hem öğretmen hem de öğrenci denek grupları için hazırlanan anketler vasıtasıyla toplanmıştır. Ayrıca, dört öğretmen ve 10 öğrenci ile de yüz yüze görüşme yoluyla sağlanan veriler de kullanılmıştır. Her iki ankette bulunan her bir soru için yüzde hesaplaması yapılmıştır. Kayıt edilen ve dokümlenen görüşmeler içerik analizi kullanılarak analiz edilmiştir. Çalışmanın bulguları öğrencilerin büyük çoğunluğunun grup aktivitelerinden hoşlanmasına rağmen öğretmenlerin sınıf yönetim zorluklarına ve yüksek gürültü nedenlerine bağlı olarak grup çalışmalarını sınıfta uygulamada çok daha az istekli olduğunu göstermektedir. Çalışma, öğretmenlerin işbirlikçi öğrenimi etkili olarak sınıfta uygulayabilmeleri ve öğrencilerine işbirlikçi aktiviteler sırasında iletişim becerilerini nasıl etkili kullanabileceklerini öğretmeleri için bu teknikle ilgili hizmetiçi eğitim almalarını önermektedir.
\end{abstract}

Anahtar kelimeler: işbirlikçi öğrenme, grup çalışması, İngilizcenin yabancı di olarak öğretilmesi
İnönü University

Eğitim Fakültesi dergisi

Cilt 19, sayı 3, 2018

ss. $582-597$

DOI: $10.17679 /$ inuefd. 385741

\section{Önerilen Atıf}

Koç, E.M.(2018). Yabancı Dil olarak Ingilizcenin Öğretildiği Sınıflarda Grup Aktivite Odaklı İşbirlikçi Öğrenmenin Incelenmesi, Inonu University Journal of the Faculty of Education, 19(3), 582-597. DOI: 10.17679/inuefd.385741 


\section{INTRODUCTION}

Collaborative Learning $(\mathrm{CL})$ posits that learning occurs as a result of social act (Gerlach, 1994). This social act refers to the talk of the participants among themselves to perform learning activities (Golub et al, 1988). Laal and Laal (2011,pg.491) in the same line define CL as 'an educational approach to teaching and learning that involves groups of learners working together to solve a problem, complete a task, or create a product.'Pair and group work are defined as collaborative learning (CL) activities (Harmer, 2001; Macaro, 1997; Ur, 1996). Brown (1994, p.159) asserts that a class that engages in cooperative learning usually has students working in pairs or groups and share information to successfully achieve their learning goals. Accordingly, in this study, pair and group work are regarded as strategies used in both collaborative and cooperative learning.

Group work regards all learners as co-learners, and it incorporates all types of learning from cooperative and collaborative group work to peer tutoring (Baines, Kutnick and Blatchford (2009, pg.8). Marks and O'Connar (2013, p.147) define group work as 'a form of cooperative learning, a technique that requires the students to work together collaboratively.' Similarly, Baines et al (2009) define group work as an activity in which learners work together as a group or team either to achieve a common purpose or to produce a specific product. Johnson and Johnson (1999,) describes five criteria to successful collaboration in the classroom:

1. Positive interdependence: Team members must understand that they have mutual responsibilities, because they need each other for support and depend on each other to accomplish their task.

2. Individual accountability: 'The purpose of a cooperative learning group is to make each member stronger...' (JohnsonandJohnson, 1999, p.71). For this criterion, the performance of each group member is assessed individually.

3. Face-to-face promotive interaction: Team members encourage each other by providing feedback and assisting and praising each other.

4. Group processing: Group members reflect on the process used to complete a task and discuss ways to improve the effectiveness of the process.

5. Social skills: Effective collaborative learning requires the effective use of interactional skills. Skills such as questioning, providing feedback, and reaching consensus are necessary for effective group functioning. These skills must be taught by the teacher and practiced by the class on a regular basis for effective interaction during group learning.

The above criteria are important to consider when structuring groups for effective collaborative learning. Group work has been carried out to enhance student motivation, school achievement, oracy development, and critical and analytical skills; to improve student behavior in class and relations with peers; and to increase student engagement in learning (p.8). Group work also encourages autonomous learning and empowers students to assume responsibility for their own learning (Baines et al., 2009). Gillies (2004) defines two types of $\mathrm{CL}$ groups: structured and unstructured. In structured groups, the learners are taught to interact appropriately, to assume individual responsibility for a common goal, to complete their own tasks for the betterment of the group, to think critically, and to reflect on their learning (Gillies and Boyle, 2008). Students in unstructured groups tend to not act cooperatively and are frequently off-task more so than their peers in structured groups (Gillies, 2004).

Communicative Language Teaching (CLT) is encouraged in schools not only in Turkey but also in many countries throughout the world. Because CLT encourages student-centeredness, the role of the teacher is less dominant in the classroom. In the CLT classroom, the teacher acts as a facilitator (Al Ashaikh, 2017; Breen and Candlin, 2001; Larsen-Freeman, 2000; Richards and Rogers, 2001). As a facilitator, his/her responsibility is to set up activities that are likely to promote communication. The teacher, as the task designer, is responsible for organizing meaningful and authentic activities, explaining the task, and the learning objectives, and the procedures to follow for academic achievement. The teacher is also responsible for assigning students to groups with regard to particular skills and ability. Feedback on student performance improves student learning (Gillies and Boyle, 2010; Kluger and DeNisi, 1996), and serves as a calibration tool for student regulation (Prevost, 2017, pg.16). In order to see the students' strengths and weaknesses a teacher should also be a good observer (Bayat, 2004). The teacher regularly monitors groups while they are in progress, observes them, and provides assistance as it is needed to help them move forward on the task (Breen and Candling, 2001).

\subsection{Theoretical framework}

Cooperative learning is encouraged because it increases classroom interaction. Vygotsy's sociocultural theory ( Vygotsky, 1978) posits that social interaction among individuals increases language development, and learning occurs through interaction and collaboration (Krange and Ludvigsen,2008) Similarly, Vygotsky's 
(1978) zone of proximal development, or the area in which the child is not successful in solving a problem but achieves and solves it under an adult's supervision, suggests that teachers need to do more than just arrange the environment so that the students discover on their own. The students should be guided by explanations, demonstrations and opportunities for cooperative learning' (Woolfolk, 1998).

Based on this theory, Woolfolk, (1998) claims that language learners develop their language proficiency when they collaborate and interact with more advanced learners. Thus, because cooperative learning enables students to receive the social support they need during learning, teachers should use pair and group activities that contribute to an encouraging atmosphere in which students can use the target language. Similarly, Richard (1990) claims that pair activities, role playing, and group activities are the types of techniques that best facilitate learning.

\subsection{Scope of the study}

Most research on $\mathrm{CL}$ focuses on the effects of $\mathrm{CL}$ on academic achievements of elementary, secondary, high school and university students (Azap, 2012; Batdi, 2013; Çokparlamış, 2010; Çopur, 2011; Dilek, 2012; Kartal, 2014; Kartal ,2012; Tekeli, 2013; Tonbul, 2001). Very few of these investigate learner perceptions or teacher perceptions of collaborative learning ( Batdı,2013;Gillies and Boyle,2011; Gillies and Boyle,2010; ; Kocaman,2005); Although scant, some research has focused on young learners' perceptions of CL (Lee and Macaro, 2013), whereas other research has focused on secondary(Day and Bryce, 2013; Gagne, 2013; Macquarrie, Howe andBoyle, 2012) or high school (Nair et al., 2012) students' perceptions of CL. Alghamdi and Gillies (2013) investigate male $10^{\text {th }}$-grade students' perceptions of CL; Mulryon (1994) investigates $5^{\text {th }}$ and $6^{\text {th }}$-grade students' perceptions of group work. Still others investigate adult learners' perceptions of $\mathrm{CL}$ (Lee and Macaro, 2013; Moore, 2013; Sarobol, 2012; Tian and Macaro, 2012). Unlike those studies, however, this study focuses on both students' (secondary and high school students) and teachers' perceptions of collaborative learning, with a specific focus on group work. Furthermore, this study aims to extend the data collected by the questionnaires through structured interviews, thus providing a more detailed perspective of the respondents' attitudes.

The aim of this study is to investigate English-language teachers and their students' views of collaborative learning and more specifically, their views of pair and group activities. The research questions driving this study are as follows:

1) What are the views of English-language teachers toward group work?

2) What are the views of EFL learners toward group work?

\subsection{Participants}

\section{METHODOLOGY}

There are two participant groups in the study. The first group consists of 25 English-language teachers working at six state schools in Turkey (Table 2). The second group of participants includes 486 secondary $\left(6^{\text {th }}, 7^{\text {th }}, 8^{\text {th }}\right.$, and $9^{\text {th }}$ grade) and high school $\left(10^{\text {th }}, 11^{\text {th }}\right.$, and $12^{\text {th }}$ grade) EFL learners (Table 1$)$. The Englishlanguage proficiency levels of the secondary- and high-school student participants are defined by their English teachers as lower- and upper-intermediate, respectively.

Table 1 Number (N) of participants

\begin{tabular}{lll}
\hline Schools & Grades & $N$ \\
\hline$A$ & $7^{\text {th }}, 8$ th & 52 \\
$B$ & $9^{\text {th }}, 10^{\text {th }}, 17^{\text {th }}$ & 80 \\
$C$ & $6^{\text {th }}, 7^{\text {th }}, 8^{\text {th }}$ & 254 \\
$D$ & $8^{\text {th }}, 9^{\text {th }}, 10^{\text {th }}$ & 100 \\
Total & & 486 \\
\hline
\end{tabular}

Table 2.Demographic information of English language teachers

\begin{tabular}{lll}
\hline \hline & Years of experience & Number of teachers $(\mathrm{N})$ \\
\hline Years of experience & $1-5$ & 12 \\
& $6-10$ & 3 \\
\multirow{3}{*}{ Gender } & $11-30$ & 10 \\
& female & 22 \\
Total & male & 3 \\
\hline
\end{tabular}

2.2. Data collection tools 


\subsubsection{The questionnaires}

Two questionnaires were used in the study. The teachers were administered a two-part teacher questionnaire. The first part collected demographic information about the EFL teachers, such as gender, teaching experience and what grade level they teach. The second part was composed of 13 items related to group and pair activities. Sample questions included the following: How often do you implement CL (pair and group) activities in the classroom? What are the difficulties that you face during group activities? At what grade level (elementary, secondary, high school) do you most prefer to implement group work? How do you arrange your students into groups (mixed ability/mixed gender/student choice)?

To collect data from EFL learners, the researcher constructed a student questionnaire. The student questionnaire contained 12 items related to students' thoughts about group and pair activities. Sample questions included the following: Which $\mathrm{CL}$ activity (pair work/group work) do you prefer in the language classroom? How often does your language teacher incorporate pair activities? How often does your language teacher incorporate group activities? How many team members do you think are appropriate for a $\mathrm{CL}$ activity? What are the advantages of group work?

Content validity for the two questionnaires was determined by a panel of experts in the field of Englishlanguage teaching. The draft versions of the questionnaires were piloted for face validity.

\subsubsection{Interviews}

After the questionnaires were administered and analyzed, semi-structured interviews were conducted by the researcher to gather more detailed information about the learners' and teachers' perceptions of group and pair activities. The interviews included structured questions and were conducted in Turkish with 10 learners and four teachers. All of the interviews were tape-recorded. Following a data analysis, the elicited quotations were translated into English.

\subsection{Data collection procedures and data analysis}

The researcher, after obtaining the schools' (required) formal permission, visited the teachers and their classes at the scheduled times to collect data. All of the participants were informed about the study's goals and procedures, and they were told that their participation was voluntary. A consent form was attached to the questionnaires and included detailed information about data collection, analysis procedures, and data confidentiality. Data collected through the teacher and student questionnaires were transferred to the computer, and the percentage of responses for each option of each question was calculated for each item on both questionnaires.

The recorded interviews were transcribed, and meaningful excerpts (ranging from a sentence to a few sentences in length) that referenced various themes were identified. Next, excerpts referencing similar themes were clustered into appropriate categories. Direct quotations from the specific categories are presented together with questionnaire data to support and/or provide a detailed view of the questionnaire data.

\section{RESULTS}

The questionnaire data for the teachers and the students, along with the interview quotations, are presented in an embedded form. The questionnaire data are separated and categorized as follows: 1) teacher and student preferences with respect to group work or pair work; 2) teacher and student views regarding the advantages of group work; 3) teacher and student views regarding difficulties encountered when implementing group activities; and 4) teacher and student views on the use of L1 in group work and pair work. Although the data do not provide any information about group composition, three categories emerged from the interview data that were specifically related to group composition. These included size, seating plans, and learner characteristics. These data are presented in this section. 


\subsubsection{Teachers' views}

Thirty percent of the teachers reported that they 'rarely or never' incorporated group work in the classroom. According to the data, most of the English-language teachers (82\%) implemented both pair and group activities. It is significant that very few (4\%) preferred 'only pair work' or 'only group work' activities. This indicates that the majority of the teachers implement different types of tasks that require different types of groups. This assumption is supported by the interview data. During the interviews, some of the teachers indicated that their preference for group work or pair work depends on the type of task being assigned. T2 stated, 'According to the topic, some of the tasks must be completed in groups.'

During the interviews, some of the teachers indicated that they preferred to implement group activities at the elementary and secondary levels because younger students are more ambitious and are more motivated to engage in these activities. One of the English teachers who taught students in the lower grades explained why she preferred group work:

T1: I guess I prefer group work when teaching younger students. When you give them an assignment, they try to do it with enthusiasm, and they really take it seriously. There is no such ambition and seriousness among high school students. Preparatory classes treat collaborative learning seriously. However, in high school, English class is not taken as seriously because it is not regarded as important, so it is more difficult to find the opportunity to practice pair-work and group-work exercises. You can practice collaborative learning only in preparatory classes at the secondary and elementary levels.

\subsubsection{Students' views}

With respect to the frequency of the implementation of group work in the classroom, the students' answers seem to conflict with those of their teachers. Although only $30 \%$ of the teachers indicated that they did not use $\mathrm{CL}$ frequently in the classroom, most of their students indicated that their English-language teachers rarely or never (63.5\%) implement group activities in the classroom.

The interview data reveal why students prefer working in groups. Our analysis of the interviews indicates that the learners prefer group-work activities in the classroom because learning collaboratively helps them to better understand the subject matter, supports the generation and exchange of ideas, and enhances their learning as a result of the assistance of their peers. The students also reported that group work provides them the opportunity to practice English with their peers. Student quotations are presented below.

On the exchange and generation of ideas:

S1: ..."The group work is proverbial. United we stand, united we are stronger.... When there are more people in the group, more ideas are created."

S2: I always want to participate in a group-work activity during the lessons because the ideas generated by my friends and those that I generate are always different. When we collect everybody's ideas, we can create more, different and better things. There is a difference when one person creates something on their own versus when 3-4 persons create something. Working together, we bring out better ideas in each other.

\subsection{Peer learning}

S4: In group work, for example, another person may know a word that you do not know. You can learn that word by receiving help from another group member. Thus, I can practice my language skills more. The pair work is boring, but the group work is more enjoyable, and I can learn the subject more easily.

S5: I understand the subject better during group work when I discuss the work with my friends. But in the case of pair work, I do not understand the subject as well.

S7: During group work, you can learn the things that you do not know from others in the group. Also, you are more interested in the lesson when there are more people in the group.

S8: Doing group work with 5-6 peers enables us to develop our vocabulary, to create different ideas, and to discuss and learn the advantages and disadvantages of different options from one another.

The results also indicated that $27.5 \%$ of the students prefer to work only in pairs or to spend more time working in pairs than not in pairs. However, $82.5 \%$ of the students favored working in groups.

Students also revealed that 22\% of English-language teachers 'rarely or never' implement group activities in the classroom, and more than half of the students reported that English-language teachers 'sometimes' implement group activities.

The results indicated that although most of the learners favor group activities, English-language teachers do not favor group work and apply it infrequently due to classroom management problems. 
3.3. The advantages of group work

3.3.1. Teachers' views

Teachers who indicated in the questionnaire that they favor group work were asked in the interview to elaborate on the reasons that they prefer group work. The data revealed that the most frequent reason provided by teachers who prefer group work and therefore implement it in the classroom was that they find that group work motivates students to learn. Other reasons provided, in the order of most- to least-often cited, include the view that group work encourages interaction, group work enhances self-esteem, and group work promotes student participation and contribution during the lesson.

T 2: I think students participate more effectively in lessons. They lack self-confidence when working alone, but in groups they express their opinions and make sure that their ideas are correct. They are more comfortable putting forward their ideas. They think group work is more entertaining. They do not get bored.

\subsubsection{Students' views}

The results indicated that like their English-language teachers, students believe that group work motivates learners and enables them to practice the target language.

\subsection{Motivation}

Nearly all of the learners (91\%) reported that group-work activities are very motivating.

S2: Group work makes me more motivated. If we do not have group activities in the classroom, the class may get bored. It is easier for me to join the discussion and try to contribute something when I am working in a group. In this situation, the lesson is more enjoyable, and time passes more quickly.

S4: Everybody participates in the group-work activities. There are no irrelevant conversations within the group, and everybody is more interested in the lesson. Because everyone else listens to the speaker, I have to listen, too.

S1: We learn different subjects and different words when working together. We discuss them collectively. Thus, the course becomes more enjoyable.

S6: I like to work with a maximum of 4 persons. Having more people in a group means that more ideas are generated. When there are several ideas, you can learn more.

\subsection{Practicing the target language}

Another finding is that most of the learners (86\%) think that group work allows them to practice speaking English, as evidenced by the following student statements.

S5: If our teacher is always the one speaking during the lesson, then we practice less. For example, if we only answer when our teacher asks us a question, we only speak about that particular paragraph or sentence in the book. However, during group work, we attempt to state some of our ideas in English, even though sometimes we speak in Turkish.

S8: We learn by listening in the classroom. But must also have conversation. That is, we learn to converse by speaking the target language. Maybe we can learn grammar patterns through exercises in the book, but how can we learn to speak in English? Group work creates this opportunity and helps us to learn English.

3.6. Difficulties in the implementation of group work

Teachers who do not approve of group-work activities or who find it difficult to implement such work in the classroom were asked to explain why they were opposed to such work. The most common response was that the students tended to speak Turkish rather than English during group work (56\%). Other reasons provided included that view that classroom conditions were not conducive to group work (28\%), the noise level associated with group work was too high (10\%), and the teacher had difficulty managing the classroom (6\%).

During the interviews, some of the elementary school teachers mentioned that the noise level was higher and classroom management was more difficult when they implemented group activities.

T4: Working in pairs is easier, of course. Younger students are very picky when selecting a partner. "I will work with him...I won't work with her...I do not want to be in this group." Pair work is less noisy than group work because students are bound to their desk mates. 
Although noise was mentioned as one of the negative outputs of group work, some teachers did not agree with this conclusion. They felt that that 'noise' was a natural outcome of the group-work activity and that it provided evidence that the students were interacting.

T3: It is easier with fewer students. In crowded classes, there will be more noise. You know, during the group work, there are always ongoing conversations among team members. This makes it difficult for the teacher to control the class.

3.7. Language usage in $\mathrm{CL}$ activities

3.7.1. Teachers' views

During the interviews, the teachers indicated that the students use both English and Turkish during group and pair activities. Teachers believe that the students speak in Turkish because they lack sufficient vocabulary knowledge and proficiency in English.

T4: They usually speak in Turkish during group work. I warn them, but their English skills are not sufficient to speak in English. They understand it but cannot speak it. Because I cannot control the class during group work, they speak in Turkish.

T1: The students use a mixture of Turkish and English or a blend of both. I have never seen anyone speaking exclusively in English. They speak mostly in Turkish, but some of their discussions are in English. If they cannot find the correct word, they ask me. However, mostly they try to manage on their own.

\subsubsection{Students' views}

The findings indicated that $66 \%$ of the students speak in Turkish during pair activities, whereas just $34 \%$ use the target language (English). The results also revealed that only $35 \%$ of the students speak in English during group activities. These results are striking because students are expected to use the target language in both pair and group work, but the reality is just the opposite: most of the students use their mother tongue in pair- and group-work activities. The students cite their low level of English proficiency as a reason for not using the target language. They also mention that they used L1 when explaining the task or a vocabulary word to each other.

S8: During pair work, if my friend has not understood the activity, I try to explain the task to him in English or Turkish.

S4: In fact, we do not generally speak in English. That is, even if you speak in English, another student answers in Turkish... I do the same. But we speak in English when we are talking to the teacher.

S4: Generally, we speak in Turkish because our English proficiency is not sufficient to make ourselves understood in English.

S 10: I cannot understand some words and phrases in English, and when I don't understand, I may miss the material. So, I prefer to use Turkish more often.

59: We have English class 4 hours a week. That is not a sufficient amount of time to learn English. Because we cannot understand English very well, we speak in Turkish more frequently during the lesson.

S2: If I knew English, I would prefer to speak in English. However, I do not know English well enough to speak it.

S3: When I speak in English, I cannot express what I intend to say clearly... and then I must speak in Turkish. S6: My vocabulary is very limited. I must ask someone the Turkish equivalent of a word that I do not know.

3.8. Group composition (size)

3.8.1. Teachers' views

According to the results of the questionnaire regarding seating during group/pair work, most of the teachers (74\%) indicated that they prefer to arrange students in groups of fours. Only $26 \%$ indicated a preference for five members in each group. None of the teachers preferred to divide students into groups of three or groups of more than five.

T2: In classrooms, the seats are in rows. So, groups must consist of four people. Three is not convenient. I prefer both pair work and group work with four students because sometimes even during pair work, partnerships are necessary. Thus, four is more convenient than three, but more than four is overcrowded.

T4: I prefer four or five students in groups. More than five students may cause inequality in the distribution of work. I know that when there are six students in a group, for example, 3 students end up doing all of the work. For me, four is perfect. But in more crowded classes, five is also acceptable. 


\subsubsection{Students' views}

The results indicated that $13 \%$ of the students prefer to work in pairs, $8 \%$ prefer working in groups of $3,23 \%$ prefer groups of 5 , and $16 \%$ prefer to work in groups of more than 5 . Forty percent prefer working in groups of 4 . Thus, the majority of the students (87\%) prefer to work in groups of three or more instead of working with a single partner (pair work).

During the interviews, the students who prefer pair work indicated that they prefer it to group work because pair work is less problematic, they feel more comfortable, and they can more easily express their ideas.

S8: When there are several people in the group, the efficiency is decreased because more people means more problems. We cannot express our thoughts as well when there are more people. If there are fewer people in the group, I have more opportunities to express my thoughts.

S7: There is no friendliness among the people in our classroom. Everybody does what he or she feels like doing. In any case, everybody gets his or her way, so I like to work with a close friend.

S4: It is better to do group work, but at this moment our in-class hours are too few. This means that we only take 3 hours of lessons. Because the group work is time-consuming, the in-class hours will be insufficient for us.

However, most of the students prefer to work in groups of 4.

S4: Having three people in a group is too few and 5 people is too many. I like to work with 4 people. We already have a group of 4 , and we always work together.

S8: Too many cooks spoil the broth... So, I would like to be in a group with a maximum of 4 persons.

S7: I do not want to work with more than 5 persons in the group because it will be too crowded and disruptive. S2: I would like to work with my best friends... They are the ones who are serious and whom I like and believe in.

S7: Generally, during pair work, partners do not help each other much. In group work, there is more work sharing. For example, there is a spokesman, a recorder, etc., in a group and everybody does their share... in groups of 5 persons. If they are my close friends, it will be more pleasant. However, it is not bad if there are other people. At least it may be better for the students who do less or need more help. I do not want to call them lazy.

S6: In fact, I want even more than 5 persons. Because it is more enjoyable... you can understand the subject more clearly and do more in-depth work. It is not important for me that the other students are hard-working. I would like to be with people who can get along, discuss the subject, and work at the same level (neither better nor worse than me).

S3: I would like to work in a group with more than 5 persons because there will be much more knowledge shared. For example, if 4 persons answered correctly and two persons answered incorrectly, then the answer of the 4 persons will likely be valid.

\subsection{Group composition (learner characteristics)}

In general, the interview data indicated that whereas teachers tend to arrange students into heterogeneous groups according to target language proficiency levels (low/moderate/high), the students seem to want to work with peers whom they know to be responsible.

\subsubsection{Teachers' views}

During the interviews, teachers indicated that the students' English-language proficiency levels are another factor affecting the formation of groups during group activities.

T2: I definitely assign groups so that there are talkative and quiet students and successful and unsuccessful students in each group. But sometimes unsuccessful students try to take advantage of successful ones. So, group work is insufficient to evaluate the success of these students. I have 24 hours each week with my preparatory classes, so I can recognize who is successful. But in the upper-level classes, this may cause problems. We often give quizzes so that teachers can identify who is really skilled and who is not.

T1: When forming groups, I prefer to mix students depending on their desk locations in class. In doing so, I try to mix passive and active or successful and unsuccessful students.

\subsubsection{Students' views}


The interview data indicated that one of the important reasons why students preferred to work in groups is that they believe they affect each other's learning. During group work, it is easier for the students to confirm the accuracy of their knowledge. In this sense, students are more positive about heterogeneous groups that contain a mixture of lower, moderate, and higher level students.

S7: In pair work, I cannot be sure that my partner is answering the question correctly. This leaves a question in my mind. However, in group work, if I am not sure about the answer to a question, I can ask others. In this way, I can find the right answer and confirm its accuracy.

Some students prefer to work with their best friends.

S8: I would like to be in a group with my best friends... they are serious students whom I like and believe in. However, for some of the students, seriousness and responsibility are important characteristics in group work. These students prefer to work with peers who are responsible.

S5: From the moment we start group work, I like to participate in a group full of honest, mature people who take the lesson seriously.

\section{DISCUSSION AND CONCLUSION}

\subsection{Group work and pair work preferences}

The results indicate that English-language teachers either do not favor group activities or find it difficult to implement them in the classroom. Group work is not a frequently preferred teaching strategy. This finding aligns with the findings of Macquarrie,HoweandBoyle(2012), Kocaman's (2005) findings also reveal that although teachers perceive group -work to be an effective technique, they use pair-work more often.. It is evident that English-language teachers find it difficult to effectively implement group activities. Such difficulty could be due to a lack of understanding and skills needed for the implementation of effective group work activities in the classroom (Doymuş and Koç,2012; Kocaman,2005).

Similarly, the literature notes that $\mathrm{CL}$ is not widely used for the promotion of learning and practice (Antil, Jenkins, WayneandvVadsay, 1998; Baines et al., 2003; Gillies, 2003; Wigglesworth and Storch, 2012). The results also reveal that English-language teachers prefer to implement group work more frequently in the lower grades. Similarly, Race and Powell (2000) report that teachers in lower grades expressed a more favorable attitude toward CL than teachers in higher grades. Whether young learners can more effectively engage in pair work or group work is an issue for further discussion. Gagne and Parks (2013) find that elementary-school (6th grade) students are capable of providing various forms of support to their peers during $\mathrm{CL}$ activities in ESL classrooms.

With respect to learners' views, the results reveal that most of the students favor group activities and find them motivating. This finding is consistent with the related literature (Çakmak,2014;Dilek,2012; Kartal,2014; Kocaman,2005;Marks and O'connar, 2013). However, one significant finding of this study is that although most of the learners have positive attitudes toward group activities, a significant number of students do not favor them. Similar findings are reported in the related literature (Çakmak,2014; Çokparlamış,2010;Kartal,2014. This finding suggests that teachers should be aware of the individual learning styles of their students and organize their activities accordingly. They should also try to understand the underlying reasons for these negative attitudes. Students might have negative attitudes toward group work because of the type of task they are asked to perform in groups. For example, some students may prefer to work alone or in pairs on grammar-focused tasks, whereas they may prefer to work in groups to practice the target language in communication-based tasks. Mishra and Oliver (1998) find that most students favor group work; however, their findings indicate that some students prefer to work individually on grammar-focused tasks because they feel they have more opportunity to practice their grammar. Consistent with this finding, Storch's (2005) results indicate that in terms of accuracy, pair work does not have an advantage over individual work for grammar-focused tasks.

\subsection{The advantages of group work}

The data gathered from teachers indicate that the most frequent reason that teachers favor group work is because it motivates their students. The impact of motivation is also mentioned in numerous studies (Çakmak,2014; Kartal, 2014; Yasul and Samancı, 2015). Other reasons for favoring group work are that it encourages interaction, student participation, and student communication during the lesson. 
One advantage of group work reported by the participants is that it enables the students to practice the target language and therefore increases their speaking time., which is also mentioned in the studies of Dilek (2012) and Kartal (2014). Kagan (1995) regards the amount of language output per student as the single greatest advantage of cooperative learning over traditional classroom teaching. In the traditional classroom, according to Kagan (1995), students are called upon one at a time. During the entire class period, the teacher does more talking than the students because he or she must talk twice for each time a student talks-first to ask a question and then to provide feedback. Kagan (1995) reports that in traditional classrooms, as much as $70 \%$ of the teacher's time is spent disciplining, lecturing, giving instructions, and asking questions. In sharp contrast, in classrooms using cooperative learning techniques, $75 \%$ of the teacher's time is spent providing feedback, facilitating student communication, and assisting students.

The interview data provide further information about why students prefer working in groups. The analysis of the interviews indicate that students define group work as a 'motivating activity' and prefer group-work activities in the classroom because they can better understand the subject matter, exchange and generate ideas, achieve more through the assistance of their peers, and have opportunities to practice the target language. Most studies on CL highlight similar advantages with respect to learning (Cohen, 1994;Sanap, 2013). More specifically, CL promotes achievement (Alghamdi and Gillies, 2013; Gillies andBoyle, 2010), socialization (Batdı,2013;Cohen, 1994; Gillies and Boyle, 2010), motivation (Kao, 2003; Lio, 2005), speaking skills (Kao, 2003; Lio, 2005), idea sharing ( Dilek,2012;Johnson and Johnson, 2003), and listening to one another (Johnson and Johnson, 2003).

\subsection{Difficulty in the implementation of group work}

In this study, the most frequently mentioned cause of difficulty in implementing group activities cited by the English-language teachers was that the students tended to speak in L1 (Turkish) instead of the target language (English) during group work. Similarly, Kocaman (2005) found that the most common problem during group-work activities was the use of native language ${ }^{\prime \prime}$ which could be due to the complicated and unclear instructions provided by the teacher. In the same line, Storch and Aldosari (2010) note that the students' use of L1 as opposed to the target language is a major concern of teachers when implementing group activities. The other reasons, from most common to least common, included inappropriate conditions for group work in the classroom (28\%), a high level of noise (10\%), and difficulty in managing the classroom (6\%). These findings are supported by Galton, Simon and Croll (1980), whose results indicate that teachers felt that the implementation of group work was difficult because it was time-consuming and the learners used L1 during the group activities. Similarly, in Çokparlamış (2010), Yasul and Samancı (2015), Kocaman (2005), Kale (2007) and Çakmak (2014 )'s studies classroom managemen issues such as noise, and student misbehaviours, are perceieved by the participants to be the potential pitfalls of group-work activities.. Gillies and Boyle (2010) find that time management was a negative factor when considering the implementation of group work. A high level of noise could be a sign that students are interacting with each other by asking questions, providing feedback, reaching consensus, etc., which are key elements of structured groups in collaborative learning. However, excessive noise could also be a sign that students are off-task and involved in irrelevant social conservation. If this is the case, it is likely that the group is unstructured. As Gillies (2004) indicates, students in unstructured groups are more likely to be off-task than their peers in structured groups. This could be because they have not received sufficient training from the teacher about the $\mathrm{CL}$ process, which is likely to indicate that the teacher does not know how to implement $\mathrm{CL}$ in the classroom.

\subsection{Language use}

Data revealed that learners prefer to use L1 more during pair and group activities. Because the students' proficiency levels ranged from low-intermediate to intermediate, their preference for using L1 may be due to their low level of English-language proficiency. Interview data also support this fact. Similarly, Guk and Kellogg (2007) have reported that in EFL contexts, L1 is used a significant portion of the time. Lee and Macaro's (2013) findings also demonstrate that younger learners prefer to use their own language more frequently to facilitate learning. Likewise, Brooks and Lewis (2009) recognize the use of L1 in EFL settings, and Moore's (2013) study also supports these findings. Swain and Lapkin (2000) also reveal that weaker pairs were more likely to use L1 than their more proficient pairs.

Another finding of this study is that learners use L1 when explaining a task or vocabulary to their peers. Similarly, Swain and Lapkin (2000) reveal that learners use L1 during interpersonal communications and when negotiating grammar and vocabulary. Anton and DiCamilla (1998) find that learners use L1 when assisting each other and negotiating metalinguistic knowledge. 


\subsection{Group composition}

With respect to group size, the results of the study indicated that most of the English-language teachers prefer groups of four, whereas a few indicated a preference for groups of five. Research in the CL literature also supports this finding (Kocaman, 2005) Similarly, the students reported that they prefered their groups to have three or more members. Day and Bryce (2013, p.1537) indicate that a typical group may contain between two and six members, with four being the ideal number., Lou, Abrami and d'Apollonia (2001) also find that students learned better in groups of three or four members.

Interview data from teachers provided more detailed reasons for the teachers' preferences in assigning students to groups. Teachers tend to organize heterogeneous groups by including low-, moderate- and high-level students in the same group. This finding partly alligns with the findings of Kocaman(2005)'s study who found that while half of the teachers considered student ability ", the other half either assigned the students randomly or let the students compose their group members when composing groups. The efficiency of such heterogeneous groups is supported in the related literature (Bennet and Dunne, 1992; Johnson andJohnson, 1994; Slavin, 1995). For example, Webb et al. (1998) find that low-ability students benefited from working with moderate and above-average students in a group, and Lou et al. (1996; 2001) find that students performed better in mixed-ability groups.

Interview data from students, however, indicated that they are prefer to work with their best friends or peers who are serious and take responsibility for successfully completing the task. Sarobol's (2012) study leads to similar conclusions, finding that some students prefer working with group members who take responsibility for their role in the group task. Abrami et al. (1995) find that students who know and like each other benefited the most from working together.

\section{Conclusion}

This study indicates that although most students favor group activities in English-language classrooms, teachers do not. The teachers in this study were not trained in $\mathrm{CL}_{\text {; }}$ therefore, whether these teachers implemented $C L$ effectively remains an open question. $C L$ does not mean simply arranging students into groups, telling them to work on an assigned task (Sarobol, 2012), and monitoring them. However, this is the approach applied by many teachers (Al-Yaseen, 2012). Therefore, although CL is an effective approach to enhancing student learning, it is underutilized in schools (Muijs and Reynolds, 2005). For this reason, teachers should receive training not only to enhance their awareness of the effectiveness of $C L$ when implemented properly but also so that they can properly train their students (Al-Yaseen, 2012; Bertucci et al, 2012; Gillies andBoyle, 2010). Research has confirmed that after training, teachers have a better understanding of what $\mathrm{CL}$ is and how they can implement the technique more effectively to enhance student learning (Al-Yaseen, 2012; Lopata, Miller andMiller, 2003). It was also found that trained teachers' students performed better (Gillies, 2008). A critical factor in the effective implementation of CL involves teaching students the appropriate skills, such as how to assist other students, ask questions, provide feedback, and think critically in a group environment (Blatchford et al 2003; Gillies and Boyle, 2008; Gillies and Ashman, 1996).

Teaching students how to take responsibility for their learning is also important for the effective implementation of $\mathrm{CL}$. When a member of the group fails to take responsibility, it means that the other members of the group must compensate and assume that member's responsibilities to accomplish the task, resulting in frustration on the part of the other (responsible) group members (Sarobol, 2012). Recently, great emphasis has been placed on teaching foreign languages to students at a younger age not just in Turkey but worldwide. Accordingly, young learners' language teachers should help their students develop the requisite interpersonal skills for effective collaboration in small groups (Johnson and Johnson, 1990).

This study does not provide any information about whether there is a significant difference among the perceptions of language learners at the secondary or high-school levels. In a follow-up study, t-tests should be conducted for each questionnaire item to investigate whether learners at different grade levels differ from each other in terms of their perceptions of $\mathrm{CL}$. The data from this study appear to support the assumption that English-language teachers do not receive sufficient training in $\mathrm{CL}$ and therefore are unable to effectively implement $\mathrm{CL}$ in their classrooms. However, to confirm this assumption, a further study that takes a detailed descriptive approach using observation should be conducted. Such a study is likely to shed light on the process of implementing collaborative activities in the EFL context and to determine whether these activities are implemented effectively.

\section{REFERENCES}


Abrami, P., Chambers, B., Poulsen, C., DeSimone, C., and Howden, J. (1995). Classroom connections: Understanding and using cooperative learning. Montreal: Harcourt Brace.

Alghamdi, R.and Gillies,R. (2013). The impact of cooperative learning in comparison to traditional learning (small groups) on EFL learners' outcomes when learning English as foreign language. Asian Social Science, 9(13), 19-27.

Al Ashaikh, R. (2017). Studying and supporting activity awareness in collaborative learning groups: using a persuasive social Actor., Unpublished Doctoral thesis, , University of London, London.

Al-Yaseen, W.S. (2012). Expectations of a group of primary school teachers trained on cooperative learning on the possibility of successful implementations. Education, 132 (2), 273-284.

Antil, L., Jenkins, J., Wayne, S., and Vadsay, P. (1998). Cooperative learning: conceptualizations, and the relation between research and practice. American Educational Research Journal, 35, 419-454.

Anton, M. and DiCamilla, F. (1998). Socio-cognitive functions of L1 collaborative interaction in the L2 classroom. Canadian Modern Language Review, 54, 314-42.

Azap, S. (2012). The effet of cooperative learning activities based on multiple intelligences theory on vocabulary learning in EFL classes, Unpublished MA thesis,. Ondokuz Mayıs University, Samsun.

Baines, E., Rubie-Davies,C. and Blatchford, P. (2009). Improving pupil group work interaction and dialogue in primary classrooms: Results from a year-long intervention study. Cambridge Journal of Education, 39 (1), 95-117.

Baines, E., Blatchford, P., and Kutnick, P. (2003). Changes in grouping practices over primary and secondary school. International Journal of Educational Research, 39, 9-34.

Baines, E., Blatchford, P. and Kutnick, P. and others (2009). Promoting effective group work in Primary Schools. London, England: Routledge.

Batdi, V. (2013). The effect of using enjoyable coopertaive learning supported educational activities on students self-efficcay skills, self-regulation strategies, metacognitive strategies, motivation and academic achievement in English language teaching, Unpublished doctoral thesis, Fırat University

Bayat, Ö. (2004). The effects of cooperative learning activities on student attitudes towards English reading courses and cooperative learning, Unpublished MA thesis, Bikent University, Ankara.

Bennett, N. and Dunne, E. (1992). Managing classroom groups. Cheltenham, England : Stanley Thornes Publishers.

Bertucci A., Johnson ,D.W, Johnson, R.T and Conte, S. (2012). Influence of group processing on achievement and perception of social and academic support in elementary inexperienced cooperative learning groups. The Journal of Educational Research, 105(5), 329-335.

Blatchford, P., Kutnick, P., Baines, E., and Galton, M. (2003). Toward a social pedagogy of classroom group work. International Journal of Educational Research, 39, 153-172.

Blatchford, P., Baines, E., Rubie-Davies, C., Bassett, P., and Chowne, A. (2006). The effect of a new approach to group work on pupil-pupil and teacher-pupil interactions. Journal of Educational Psychology, 98, 750-765.

Breen, M. P., and Candlin, C. (2001). The essentials of a communicative curriculum in language teaching. In D. Hall and A. Hewings (Eds.), Innovation in English language teaching: A reader (pp. 9-26). London, England: Routledge.

Brown, H.D. (1994). Teaching by principles: An interactive approach to language pedagogy. Englewood Cliffs, NJ :Prentice Hall

Çakmak, M. (2014). Grup çalışmasına yönelik yansımalar: Öğretmen adaylarının Düşüceleri, 39(174), 338-347

Cohen, E. G. (1994). Designing group work (2nd ed.). New York, USA: Teachers College Press.

Cohen, E. G. (1994). Restructuring the classroom: Conditions for productive small groups. Review of Educational Research, 64(1), 1-35.

Çokparlamış, A. (2010). Effects of cooperative learning on teaching English to young learners. Unpublished MA thesis, Çukurova University, Adana.

Çopur, G. (2011). The effect of cooperative learning on the four skills of English language department students, Unpublished MA thesis, Hacettepe University, Ankara.

Day, S. P. and Bryce. G. (2013). The benefits of cooperative learning to socio-scientific discussion in secondary school science. International Journal of Science Education, 35(9), 1533-1560.

Dilek, I. (2012). A quasi-experimental study on the effcets of cooperative learning activities in reading classes.. Unpublished MA thesis, Karadeniz Technical University, Trabzon.

Doymuş, K. (2007). Teaching chemical equilibrium with the jigsaw technique. Research in cience Education, $38(2), 249-260$. 
Gagne,N, and Parks, S. (2013). Cooperative learning tasks in a Grade 8 intensive ESL class: Role of scaffolding. Language Teaching Research, 0(0), 1-22.

Galton,M., Simon,B., and Croll, E. (1980). Inside the primary classroom. London, England: Routledge and Kegan Paul.

Gerlach, J. M. (1994). Is this collaboration? In Bosworth, K. and Hamilton, S. J. (Eds.), Collaborative Learning: Underlying Processes and Effective Techniques, New Directions for Teaching and Learning, No. 59. (pp.5-14). San Francisco; USA, Jossey-Bass Publishing

Gillies, R., and Ashman, A. (1996). Teaching collaborative skills to primary school children in classroom-based work groups. Learning and Instruction, 6, 187-200.

Gillies, R. (2004). The effects of communication training on teachers' and students' verbal behaviors during cooperative learning. International Journal of Educational Research, 41, 257-279.

Gillies, R. (2003). Structuring cooperative group work in classrooms. International Journal of Educational Research, 39, 35-49

Gillies, R. (2008). The effects of cooperative learning on junior high school students' behaviors, discourse, and learning during a science-based learning activity. School Psychology International, 29, 328-347.

Gillies, R.M., and Boyle, M. (2008). Teachers' discourse during cooperative learning and their perceptions of this pedagogical practice. Teaching and Teacher Education, 24, 1333-1348.

Gillies, R.M. and Boyle, M. (2010). Teachers' reflections on cooperative learning: Issues of implementation. Teaching and Teacher Education, 26,933-940.

Guk, H. and Kellogg, D. (2007). The ZPD and whole class teaching: Teacher-led and student-led interactional mediation of tasks. Language Teaching Research, 11, 281-99.

Johnson, D. and Johnson, R. (1990). Cooperative learning and achievement. In S. Sharan (Ed.), Cooperative learning: Theory and research (pp. 23-37). New York, USA: Praeger

Johnson, D. W. and Johnson, R. T. (1999). Making cooperative learning work. Theory into Practice, 38(2), 6773.

Kagan, S. (1995). We can talk: Co-operative learning in the elementary ESL classroom. ERIC DIGEST, No: ED382035.

Kao, E. S. (2003). The effectiveness of small-group discussion on the improvement of EFL learners' reading ability in large. Taipei, Taiwan: Tamkang University Press.

Kale, N. (2007). Drama temelli öğrenme ile işbirlikli öğrenmenin yedinci sınıf öğrencilerinin geometri başarıları, geometriye yönelik tutumları ve Van Hiele geometrik düşünme düzeylerine göre karşılaştırılması. Yüksek lisans tezi, Middle East technical University ${ }_{\text {, }}$ Ankara

Kartal, M.Y. (2012). An investigation into the effets of using cooperative learning activities on vocabulary learning in the 10th grade English course, Unpublished MA thesis, . Çanakkale Onsekiz Mart University, Çanakkale.

Kartal, Ş. (2014). The effects of cooperative learning method on students' attitudes towards English classes and their achievements: Nevşehir Universitesi, Unpublished doctorate thesis, Inonu University, Malatya.

Kluger, A., and DeNisi, A. (1996). The effects of feedback interventions on performance: a historical review, a meta-analysis, and a preliminary feedback intervention theory. Psychological Bulletin, 119, 254-284

Kocaman, P. (2005). Teachers' beliefs about group work and their application of group work in the ELT classroom, Unpublished MA theis, Mugla University, Muğla.

Krange I. and Ludvigsen S. (2008) 'What is mean?' Students' procedural and conceptual problem solving in a CSCL environment designed within the field of science education. International Journal of Computer-supported Collaborative Learning, 3, 25-51.

Laal, M. And Laal, M. ( 2011). Collaborative learning: What is it? Procedia- Social and behavioral Sciences, 31, 491-495.

Larsen-Freeman, D. (2000). Techniques and principles in language teaching (2nd ed.). New York, USA: Oxford University

Press.Lee, J. H. and Macaro, E. (2013). Investigating age in the use of L1 or English- only instruction: Vocabulary acquisition by Korean EFL learners. The Modern Language Journal, 97(4), 887-901.

Liao, H. C. (2005). Effects of cooperative learning on motivation, learning strategy utilization, and grammar achievement of English language learners in Taiwan (unpublished doctoral dissertation), University of New Orleans, USA.

Lightbown, P. and Spada, N. (1999) How languages are learned ( $2^{\text {nd }}$ ed.). New York: Oxford University Press.

Lopata, C., Miller, K., and Miller, R. (2003). Survey of actual and preferred use of cooperative learning among exemplar teachers. The Journal of Educational Research, 96, 232-241 
Lou, Y., Abrami, P., Spence, J., Poulsen, C., Chambers, B., and d'Apollonia, S. (1996). Within-class grouping: a meta-analysis. Review of Educational Research, 66, 423-458.

Lou, Y., Abrami, P., and d'Apollonia, S. (2001). Small group and individual learning with technology: a metaanalysis. Review of Educational Research, 71, 449-521.

Harmer, J. (2001). The practice of English language teaching (3rd edition), London, England: Longman.

Macaro, E. (1997). Target language, collaborative learning and autonomy. Clevedon: Multilingual Matters.

MacQuarrie, S., Howe, C. and Boyle, C. (2012). Exploring the characteristics of small groups within science and English secondary classrooms, Cambridge Journal of Education, 42(49), 527-546.

Marks, M.B. and O'Connor, A. H. (2013) Understanding students' attitudes about group work: What does this suggest for instructors of business? Journal of Education for Business, 88(3), 147-158.

Mishra, S. and Oliver, R. 1998: Secondary school ESL learners' perceptions of pair work in Australian classrooms. TESOL in Context, 8(2), 19-23.

Moore, P.J. (2013). An emergent perspective on the use of the first language in the English as as a foreign language classroom. The Modern Language Journal, 97(1),239-253.

Muijs, D. and Reynolds, D. (2005). Effective teaching: Evidence and practice (2nd ed.). London, England: Sage Publications.

Mulryan, C. (1994). Perceptions of intermediate students' cooperative small-group work in mathematics. Journal of Educational Research, 87, 280-291.

Nair, G.K.S., Rahim, R.A., Adam, A.F.M., Setia, R. Seman, N.A. (2012). Group work in the secondary ESL classroom. Asian Social Science, 8(10), 3-7.

Ngeow, K. (1998). Motivation and transfer in language learning. ERIC No. ED 427318.

Race, K., and Powell, K. (2000). Assessing students' perceptions of classroom methods and activities in the context of outcomes-based evaluation. Evaluation Review, 24, 635-646.

Richards, J., and Rodgers, T. (2001). Approaches and methods in language teaching (2nd ed.). Cambridge, England: Cambridge University Press.

Sanap, A.N. (2013, May). Effectiveness of collaborative strategies used in teaching history or achievment and interest in history at secondary school level. Golden Research Thoughts, 2(11).

Sarobol, N. (2012). Implementing cooperative learning in English language classroom: Thai University's students' perceptions. The International Journal of Interdisicplinary Social Sciences, 6(10),111-122.

Slavin, R. E. (1995). Cooperative learning: Theory, research, and practice. Boston: Allyn and Bacon

Storch, N. (2005). Collaborative writing: Product, process and students' reflection. Journal of Second Language Writing, 14, 153-173.

Storch, N., and Aldosari, A. (2010). Learners' use of L1 (Arabic) in pair work activity in an EFL class. Language Teaching Research, 14, 355-376.

Swain, M., and Lapkin, S. (2000). Task based second language learning: the uses of the first language. Language Teaching Research, 4, 251-274.

Tekeli, S. (2013). The effects of cooperative learning on students' writing performance. Unpublished MA theisis,. Çağ University, Mersin..

Tian, L., and Macaro, E. (2012). Comparing the effect of teacher codes-witching with English-only explanations on the vocabulary acquisition of Chinese university students: A lexical focus-on-form study. Language Teaching Research, 16(3), 367-391.

Tonbul, C. (2001). The effectss of cooperative learning and traditional methods on English achievement, satisfaction and retention and students opinions about cooperative learning. Unpublished MA thesis, Dokuz Eylül University, İzmir

Ur, P. (1996). A course in language teaching: Practice and theory. Cambridge: Cambridge University Press.

Webb, N., Nemer, K., Chizhik, A., and Sugrue, B. (1998). Equity issues in collaborative group assessment: group composition and performance. American Educational Research Journal, 35, 607-651.

Wigglesworth, G. and Storch, N. (2012). What role for cooperation in writing and writing feedback. Journal of Second Language Writing, 21, 364-374.

Woolfolk, A. (1998). Educational psychology (7th ed.). Boston, MA: Allyn and Bacon

Vygotsky, L. S. (1978) Mind in Society. Cambridge, Mass.: Harvard University Press.

Yasul, A.F and Samancı, O. (2015). Sınıf öğretmenlerinin grup çalışmasına ilşikin görüşlerinin incelenmesi. Iğdir University Journal of Social Sciences, 7, 131-156.

İletişim/Correspondence*

Dr. Öğret. Üyesi Ebru Melek KOÇ ebrumelekkoc@gmail.com 